\title{
Treatment of displaced intra-articular calcaneus fractures: a current concepts review
}

\author{
Mandeep S. Dhillon and Sharad Prabhakar* \\ Department of Orthopaedics, Post Graduate Institute of Medical Education and Research, Sector 12, Chandigarh 160012, India
}

Received 6 February 2017, Accepted 28 July 2017, Published online 16 October 2017

\begin{abstract}
Displaced Intra-Articular Calcaneus fractures (DIACFs) represent a source of tremendous disability to the patient, economic burden to the society and a treatment challenge to the average orthopaedic surgeon. To date, no single approach is universally applicable to all calcaneus fractures. Despite a plethora of published meta-analyses and recent randomized controlled trials, the literature is still unclear and offers conflicting recommendations. The aim of this current concepts review is to assess the latest available data and offer pragmatic and practical recommendations to address some of the issues surrounding DIACFs.
\end{abstract}

Key words: Displaced intra-articular calcaneus fractures, Current concepts review.

\section{Introduction}

Displaced Intra-Articular Calcaneus fractures (DIACFs) represent a source of potential disability to the patient, economic burden to the society and a treatment challenge to the average orthopaedic surgeon. To date, no single approach is universally applicable to all calcaneus fractures [1]. The goal of treatment has been accurate anatomic reduction, stable fixation with the aim of early functional rehabilitation while avoiding potentially devastating soft tissue complications $[2,3]$. It is also well established that pre-existing co-morbidities such as peripheral vascular disease, diabetes and smoking adversely affect wound healing following open reduction and internal fixation (ORIF) of calcaneus fractures [4, 5]. However, despite several published meta-analyses and recent randomized controlled trials, the literature is still unclear and offers conflicting recommendations $[1,2,4]$. The aim of this current concepts review is to sift through the data and offer pragmatic recommendations to address some of the issues surrounding DIACFs.

\section{Operative versus nonoperative treatment}

It has been well established that patients with DIACFs have poorer functional results than those for other orthopaedic conditions [6]. Buckley et al. [2] in their randomized controlled trial in 2002 stated that without stratification of the groups, the functional results of treatment of DIACFs operative or

\footnotetext{
*Corresponding author: sharad.ortho@gmail.com
}

nonoperatively were similar. However, it was pointed out by the authors that women, younger patients ( $<29$ yrs old), those not receiving workers' compensation, lighter workload, anatomical reduction or a step-off $<2 \mathrm{~mm}$ after surgical reduction had significantly better functional scores following surgery.

Over the past ten years a large number of randomized controlled trials have been conducted by various authors $[2,3,5,7-14]$ in an attempt to determine the efficacy of open reduction and fixation of calcaneus fractures versus nonoperative treatment (Table 1). However, given the varying sample sizes and periods of follow-up, no definite conclusions can be drawn. While authors like Agren et al. [5], Bahari Kashani et al. [8], Nouraei and Moosa [9] and Dooley et al. [12] supported operative intervention with selected indications, others reported equivocal findings [10, 11, 15].

A number of meta-analyses [16-26] have also been published on displaced intra-articular calcaneal fractures (Table 2). However, almost all studies cite insufficient evidence to make a recommendation. Others like Zhang et al. [16], Luo et al. [17] and Liu et al. [18] have stated that surgical interventions in the hands of experienced surgeons have better outcomes and less subtalar fusions are subsequently required.

Bruce and Sutherland in their Cochrane review [20] published in 2013 stated that there was insufficient high-quality evidence to establish whether surgical or nonoperative treatment is better for DIACFs. The authors did mention however that the Buckley et al. [2] trial formed a large part of the review. Furthermore, the majority of the procedures (73\%) were conducted by a single experienced surgeon and 
Table 1. Overview of existing randomized controlled trials on operative vs nonoperative treatment of calcaneus fractures.

\begin{tabular}{|c|c|}
\hline Author, Year & Findings \\
\hline Griffin et al. 2014 [7] & $\begin{array}{l}\text { - UK HeFt trial. } \\
\text { - Operative treatment compared with nonoperative care showed no symptomatic or functional } \\
\text { advantage. } \\
\text { - Risk of complications was higher after surgery. } \\
\text { - Stated that operative treatment by open reduction and internal fixation is not recommended for } \\
\text { these fractures. }\end{array}$ \\
\hline Agren et al. 2013 [5] & $\begin{array}{l}\text { - } 42 \text { operative group, } 40 \text { nonoperative. } \\
\text { - Operative treatment was not superior in managing displaced intra-articular calcaneal fractures at } \\
\text { one year of follow-up. } \\
\text { - Appeared to have some benefits at eight to twelve years. } \\
\text { - Operative treatment was associated with a higher risk of complications but a reduced prevalence } \\
\text { of posttraumatic arthritis. }\end{array}$ \\
\hline Bahari et al. 2013 [8] & $\begin{array}{l}\text { - } 84 \text { operative group, } 56 \text { nonoperative group. } \\
\text { - Stated that surgical treatment is the method of choice. } \\
\text { - Fewer complications in operative group. }\end{array}$ \\
\hline Nouraei and Moosa 2011 [9] & $\begin{array}{l}\text { - } 31 \text { operative, } 30 \text { nonoperative. } \\
\text { - Open reduction and internal fixation of displaced calcaneal fractures in the absence of open } \\
\text { fracture, severe osteoporosis, or comminution, poor general condition may be the preferred } \\
\text { method of treatment. }\end{array}$ \\
\hline Sharma and Dogra 2011 [10] & $\begin{array}{l}\text { - } 15 \text { operative, } 15 \text { nonoperative. } \\
\text { - No significant difference in outcomes. }\end{array}$ \\
\hline Ibrahim et al. 2007 [11] & $\begin{array}{l}\text { - } 15 \text {-year follow-up of displaced intra-articular calcaneal fractures from a randomized controlled } \\
\text { trial of conservative versus operative treatment published in } 1993 \text {. } \\
\text { - } 15 \text { operative, } 11 \text { nonoperative. } \\
\text { - No significant difference in outcomes. }\end{array}$ \\
\hline Dooley et al. 2004 [12] & $\begin{array}{l}\text { - } 23 \text { operative, } 24 \text { nonoperative. } \\
\text { - Do not definitively support primary operative intervention for bilateral calcaneal fractures. }\end{array}$ \\
\hline Howard et al. 2003 [3] & $\begin{array}{l}\text { - } 226 \text { operative, } 233 \text { nonoperative. } \\
\text { - Outcome scores in this study tend to support ORIF for calcaneal fractures. } \\
\text { - ORIF patients are more likely to develop complications. }\end{array}$ \\
\hline Buckley et al. 2002 [2] & $\begin{array}{l}\text { - Without stratification of the groups, the functional results after nonoperative care of displaced } \\
\text { intra-articular calcaneal fractures were equivalent to those after operative care. } \\
\text { - After removal of the patients who were receiving Workers' compensation, the outcomes were } \\
\text { significantly better in some groups of surgically treated patients. }\end{array}$ \\
\hline Rodriguez-Merchan et al. 1999 [13] & $\begin{array}{l}\text { - } 28 \text { operative, } 30 \text { nonoperative. } \\
\text { - Results better in surgically treated patients. }\end{array}$ \\
\hline Thordarson and Krieger 1996 [14] & $\begin{array}{l}\text { - } 15 \text { operative, } 11 \text { nonoperative. } \\
\text { - Operative treatment had superior results. }\end{array}$ \\
\hline Parmar et al. 1993 [15] & $\begin{array}{l}\text { - } 25 \text { operative, } 31 \text { nonoperative. } \\
\text { - No significant difference. }\end{array}$ \\
\hline
\end{tabular}

once the workers' compensation cases were excluded, surgical outcomes improved in subgroup analysis. They also suggested that subgroup analysis was conducted and presented across multiple publications [27-33], resulting in different sample sizes, time to follow-up and reanalysis of primary outcomes. The authors also mentioned that data from the then just concluded multicentric UK Heel Fracture Trial $(\mathrm{HeFt})$ was eagerly awaited.

The UK Heel Fracture trial (HeFt) by Griffin et al. [7] was published in July 2014 as a pragmatic, multicentric, two-arm, parallel group, assessor blinded randomized controlled trial with the sensational claim that operative treatment compared with nonoperative care showed no symptomatic or functional advantage after two years in patients with DIACFs, and the risk of complications was higher after surgery. Thus ORIF was not recommended for calcaneus fractures.

The trial was severely criticized by several researchers for faulty methodology. Gandhi et al. [34] stated that the "baby had been thrown out with the bathwater". Pearce et al. [35] pointed out that selection bias was a key determining factor. Only 502 of 2006 patients with calcaneal fractures were found eligible for randomization in this study. Furthermore, only 151 of 502 patients agreed to take part in the study, representing a meager $7.5 \%$ of all of the calcaneal fractures attending the centres involved in the study. Twenty-seven surgeons in 22 different hospitals operated on a median of only two fractures for this study. Most of the severely displaced fractures requiring surgical treatment had been excluded from the study. 
Table 2. Overview of meta-analysis on displaced intra-articular calcaneus fractures.

\begin{tabular}{|c|c|}
\hline Author, Year & Patients pooled, Conclusions \\
\hline Zhang et al. 2016 [16] & $\begin{array}{l}\text { - } 908 \text { patients. } \\
\text { - Surgical outcomes are based on experience. } \\
\text { - Improvement in gait and shoe wear after surgery. }\end{array}$ \\
\hline Luo et al. 2016 [17] & $\begin{array}{l}\text { - } 824 \text { patients. } \\
\text { - Less subtalar fusions but more complications after ORIF. } \\
\text { - Insufficient evidence for recommendations. }\end{array}$ \\
\hline Liu et al. 2015 [18] & $\begin{array}{l}\text { - } 966 \text { patients. } \\
\text { - Surgery protects against subtalar arthrodesis. }\end{array}$ \\
\hline Dhillon and Gahlot 2014 [19] & $\begin{array}{l}\text { - } 703 \text { patients. } \\
\text { - Insufficient evidence. }\end{array}$ \\
\hline Bruce and Sutherland 2013 [20] & $\begin{array}{l}\text { - } 602 \text { patients. } \\
\text { - Insufficient evidence. }\end{array}$ \\
\hline Jiang et al. 2012 [21] & $\begin{array}{l}\text { - } 891 \text { patients. } \\
\text { - Surgery is probably the optimal choice. }\end{array}$ \\
\hline Gogoulias et al. 2009 [22] & $\begin{array}{l}\text { - } 611 \text { patients. } \\
\text { - Insufficient evidence. }\end{array}$ \\
\hline Bondi et al. 2007 [23] & $\begin{array}{l}\text { - } 557 \text { patients. } \\
\text { - Not possible to draw conclusions. }\end{array}$ \\
\hline Bajammal et al. 2005 [24] & $\begin{array}{l}\text { - } 534 \text { patients. } \\
\text { - Insufficient evidence. }\end{array}$ \\
\hline Randle et al. 2000 [25] & $\begin{array}{l}\text { - } 242 \text { patients. } \\
\text { - Patients with operative intervention tend to return to work earlier. }\end{array}$ \\
\hline Bridgman et al. 2000 [26] & $\begin{array}{l}\text { - } 134 \text { patients. } \\
\text { - Insufficient evidence. }\end{array}$ \\
\hline
\end{tabular}

Buckley et al. [36], in a commentary in response to the study in 2015, reiterated that younger patients with simple DIACFs and without workers' compensation do well surgically. DIACFs need to be managed by specialty surgeons. Nonoperative treatment of DIACFs leads to more subtalar fusions. Future trends point towards limited open reductions with small incisions and a lower risk of complications.

\section{Extensile versus minimally invasive approaches}

The conventional extensile lateral approach remains the "gold standard" to which other minimally invasive approaches are compared [37]. Minimally invasive techniques (MIS) have been devised to overcome the wound complications associated with the conventional lateral approach [1]. MIS refers to a plethora of limited incision approaches or percutaneous fixation relying on indirect reduction techniques under image intensification or even arthroscopy assisted $[38,39]$. A recent systematic review by van Hoeve and Poeze in 2016 [40] states that percutaneous reduction and screw osteosynthesis and minimally invasive open techniques resulted in significantly better outcomes compared with external fixation and other techniques. Out of the 46 studies included in the review, covering 2018 calcaneus fractures, only one study by Chen et al. [41] was a randomized controlled trial comparing outcomes between percutaneous screw fixation and cementing or conventional ORIF in calcaneus fractures. A recent randomized controlled trial published by Khurana et al. [42] stated that an extensile approach in a tertiary care hospital, in the hands of an experienced surgeon, has better outcomes. However, the MIS group in the study was a heterogenous group including both percutaneous and limited open approaches. Thus there is paucity of highquality evidence in the literature to make any firm recommendations.

Minimally invasive approaches are therefore considered to be ideal for patients with compromised skin conditions, associated comorbidities like diabetes or smoking. However, the interventions are limited by the fact that reductions are easier to achieve earlier within two weeks [1].

\section{Primary subtalar arthrodesis}

It has been argued that in Sanders type IV fractures, articular comminution and cartilage injury are severe enough to preclude satisfactory joint reduction and thus primary ORIF and subtalar arthrodesis is an option [1]. Buckley et al. [43] in 2014 in a small randomized controlled trial were unable to demonstrate a significant difference in outcomes between ORIF alone and ORIF with subtalar fusion for Sanders type IV fractures. However, the authors stated that a primary fusion may decrease time away from work and may be economically beneficial.

Dhillon et al. [44] responded to Buckley et al.'s results stating that advocating primary fusion in Sanders IV type fractures was incorrect since only $25 \%$ of patients would eventually need fusion. Furthermore, patients with subtalar fracture dislocations, bilateral Sanders IV were not assessed for primary fusion. 
Currently, there is no clear evidence to refute or favour primary subtalar arthrodesis.

\section{The myth of the "constant fragment"}

The soft tissue attachments, along with the interosseous talocalcaneal ligaments which bind the sustentaculum to the talus, have historically led to the sustentaculum being described as the "constant fragment" [45]. Traditionally ORIF via a lateral approach involved reducing the lateral fragments to the sustentaculum tali fragment. Berberian et al. in 2013 [46] retrospectively reviewed the computed tomography (CT) scans of 88 patients with 100 DIACFs for evidence of sustentacular displacement and found that the fragment was displaced in $40 \%$ of fractures. Gitajin et al. in 2014 [47] reported similar results in $20 \%$ of DIACFs. However currently, there is no data to evaluate a combined medial and lateral approach and its effect on the functional outcome.

\section{Conclusion}

DIACFs are injuries which demand specialist intervention. RCTs and inconclusive meta-analysis underscore the fact that no single approach can be applied as a generalization to all calcaneal fractures. Operative intervention in defined subsets with anatomical reduction and meticulous soft tissue dissection yields favourable outcomes. Minimally invasive or limited open approaches, either image intensifier or arthroscopy assisted, have shown promising results. In all, a thorough evaluation of the patient and his comorbidities, the fracture pattern and soft tissue coverage and the surgeon and his level of skill and experience are required before deciding a line of treatment.

\section{Conflict of interest}

The authors declare that they have no conflict of interest in relation with this paper.

\section{References}

1. Sharr PJ, Mangupli MM, Winson IG, Buckley RE (2016) Current management options for displaced intra-articular calcaneal fractures: non-operative, ORIF, minimally invasive reduction and fixation of primary ORIF and subtalar arthrodesis. A contemporary review. Foot Ankle Surg 22, 1-8.

2. Buckley R, Tough S, McCormack R, Pate G, Leighton S, Petrie D et al. (2002) Operative compared with non-operative treatment of displaced intra-articular calcaneal fractures: a prospective, randomised, controlled multicentre trial. J Bone Joint Surg Am 84, 1733-1734.

3. Howard J, Buckley R, McCormack R, Pate G, Leighton R, Petrie D et al. (2003) Complications following management of displaced intra-articular calcaneal fractures: a prospective randomised trial comparing open reduction internal fixation with non-operative management. J Ortho Trauma 17(4), 241-249.
4. Agren PH, Mukka S, Tullberg T, Wertenberg P, Sayed-Noor AS (2014) Factors affecting long-term treatment results of displaced intraarticular calcaneal fractures: a post hoc analysis of a prospective, randomized, controlled multicenter trial. J Orthop Trauma 28(10), 564-568.

5. Agren PH, Wretenberg P, Sayed-Noor AS (2013) Operative versus non-operative treatment of displaced intra-articular calcaneal fractures: a prospective, randomized, controlled multi-center trial. J Bone Joint Surg Am 95, 1351-1357.

6. Van Tetering EAA, Buckley RE (2004) Functional outcome (SF-36) of patients with displaced calcaneal fractures compared with SF-36 normative data. Foot Ankle Int 25, 733-738.

7. Griffin D, Parsons N, Shaw E, Kulikov Y, Hutchinson C, Thorogood M et al. (2014) Operative versus non-operative treatment for closed, displaced, intra-articular fractures of the calcaneus: randomised controlled trial. BMJ 349, g4483.

8. Bahari Kashani M, Kachooei AR, Ebrahimi H, Peivandi MT, Amelfarzad S, Bekhradianpoor $\mathrm{N}$ et al. (2013) Comparative study of peroneal tenosynovitis as the complication of intraarticular calcaneal fracture in surgically and non-surgically treated patients. Iran Red Crescent Med J 15(10), e11378.

9. Nouraei MH, Moosa FM (2011) Operative compared to nonoperative treatment of displaced intra-articular calcaneal fractures. J Res Med Sci 16, 1014-1019.

10. Sharma V, Dogra A (2011) Sanders type II calcaneum fractures: surgical or conservative treatment? A prospective randomized trial. J Clin Orthop Trauma 2, 35-38.

11. Ibrahim T, Rowsell M, Rennie W, Brown AR, Taylor GJ, Gregg PJ (2007) Displaced intra-articular calcaneal fractures: 15-year follow-up of a randomised controlled trial of conservative versus operative treatment. Injury 38, 848-855.

12. Dooley P, Buckley R, Tough S, McCormack B, Pate G, Leighton R, Petrie D, Galpin B (2004) Bilateral calcaneal fractures: operative versus nonoperative treatment. Foot Ankle Int 25, 47-52.

13. Rodriguez-Merchan EC, Galindo E (1999) Intra-articular displaced fractures of the calcaneus. Operative vs non-operative treatment. Int Orthop 23, 63-65.

14. Thordarson DB, Krieger LE (1996) Operative vs. nonoperative treatment of intra-articular fractures of the calcaneus: a prospective randomized trial. Foot Ankle Int 17, 2-9.

15. Parmar HV, Triffitt PD, Gregg PJ (1993) Intraarticular fractures of the calcaneus treated operatively or conservatively. A prospective study. J Bone Joint Surg Br 75, 932-937.

16. Zhang W, Lin F, Chen E, Xue D, Pan Z (2016) Operative versus nonoperative treatment of displaced intra-articular calcaneal fractures: a meta-analysis of randomized controlled trials. J Orthop Trauma 30(3), e75-e81.

17. Luo X, Li Q, He S, He S (2016) Operative versus nonoperative treatment for displaced intra-articular calcaneal fractures: a meta-analysis of randomized controlled trials. J Foot Ankle Surg 55, 816-823.

18. Liu Y, Li Z, Li H, Zhang Y, Wang P (2015) Protective effect of surgery against early subtalar arthrodesis in displaced intra-articular calcaneal fractures: a meta-analysis. Medicine (Baltimore) 94(45), e1984.

19. Dhillon MS, Gahlot N (2014) Are results of surgical treatment for calcaneal fractures better than non-operative treatment? J Foot Ankle Surg Asia-Pacific 1(1), 17-23. 
20. Bruce J, Sutherland A (2013) Surgical versus conservative interventions for displaced intra-articular calcaneal fractures. Cochrane Database Syst Rev (1) CD008628, DOI: 10.1002/ 14651858.CD008628.pub2.

21. Jiang N, Lin QR, Diao XC, Wu L, Yu B (2012) Surgical versus nonsurgical treatment of displaced intra-articular calcaneal fracture: a meta-analysis of current evidence base. Int Orthop $36,1615-1622$.

22. Gougoulias N, Khanna A, McBride DJ, Maffulli N (2009) Management of calcaneal fractures: systematic review of randomized trials. Br Med Bull 92, 153-167.

23. Bondì R, Padua R, Bondì L, Battaglia A, Romanini E, Campi A (2007) Treatment of calcaneal fractures: the available evidence. J Orthop Trauma 8(1), 36-41.

24. Bajammal S, Tornetta P 3rd, Sanders D, Bhandari M (2005) Displaced intra-articular calcaneal fractures. J Orthop Trauma 19, 360-364.

25. Randle JA, Kreder HJ, Stephen D, Williams J, Jaglal S, Hu R (2000) Should calcaneal fractures be treated surgically? A meta-analysis. Clin Orthop Relat Res 377, 217-227.

26. Bridgman SA, Dunn KM, McBride DJ, Richards PJ (2000) Interventions for treating calcaneal fractures. Cochrane Database Syst Rev (2), CD001161.

27. Tufescu TV, Buckley R (2001) Age, gender, work capability, and worker's compensation in patients with displaced intraarticular calcaneal fractures. J Orthop Trauma 15(4), 275-279.

28. Howard JL, Buckley R, McCormack R, Pate G, Leighton R, Petrie D et al. (2003) Complications following management of displaced intra-articular calcaneal fractures: a prospective randomized trial comparing open reduction internal fixation with nonoperative management. J Orthop Trauma 17(4), 241-249.

29. Barla J, Buckley R, McCormack R, Pate G, Leighton R, Petrie D et al. (2004) Displaced intraarticular calcaneal fractures: long-term outcome in women. Foot Ankle Int 25(12), 853-856.

30. Buckley RE, Loucks C (1997) Bohler's angle-correlation with long-term outcome in displaced intra-articular calcaneal fractures. Orthopaedic Transactions 21(4), 1349-1350.

31. Kingwell S, Buckley R, Willis N (2004) The association between subtalar joint motion and outcome satisfaction in patients with displaced intraarticular calcaneal fractures. Foot Ankle Int 25(9), 666-673.

32. O'Brien J, Buckley R, McCormack R, Pate G, Leighton R, Petrie D et al. (2004) Personal gait satisfaction after displaced intraarticular calcaneal fractures: a 2-8 year follow-up. Foot Ankle Int 25, 657-665.

33. Brauer CA, Manns BJ, Ko M, Donaldson C, Buckley R (2005) An economic evaluation of operative compared with nonoperative management of displaced intra-articular calcaneal fractures. J Bone Joint Surg Br 87(12), 2741-2749.
34. Gandhi R, Perruccio AV, Kakar S, Haddad FS (2015) Putting the baby back in the bathwater. Bone Joint J, 97-B(11), 1456-1457.

35. Pearce CJ, Wong KL, Calder JDF (2015) Calcaneal fractures: selection bias is the key. Bone Joint J 97-B, 880-882.

36. Buckley R (2015) Commentary. Evidence based orthopaedics. J Bone Joint Surg Am 97, 341.

37. Schepers T, van Lieshout EMM, van Ginhoven TM, Heetveld MJ, Patka P (2008) Current concepts in the treatment of intraarticular calcaneal fractures: results of a nationwide survey. Int Ortho 32(5), 711-715.

38. Schuberth JM, Cobb MD, Talarico RH (2009) Minimally invasive arthroscopically-assisted reduction with percutaneous fixation in the management of intra-articular calcaneal fractures: a review of 24 cases. J Foot Ankle Surg 48(3), 315-322.

39. Arastu M, Sheehan B, Buckley R (2014) Minimally invasive reduction and fixation of displaced calcaneal fractures: surgical technique and radiographic analysis. Int Orthop 38(3), $539-545$.

40. van Hoeve S, Poeze M (2016) Outcome of minimally invasive open and percutaneous techniques for repair of calcaneal fractures: a systematic review. J Foot Ankle Surg 55(6), $1256-1263$.

41. Chen L, Zhang G, Hong J, Lu X, Yuan W (2011) Comparison of percutaneous screw fixation and calcium sulfate cement grafting versus open treatment of displaced intra-articular calcaneal fractures. Foot Ankle Int 32(10), 979-985.

42. Khurana A, Dhillon MS, Prabhakar S, John R (2017) Outcome evaluation of minimally invasive surgery versus extensile lateral approach in management of displaced intraarticular calcaneal fractures: a randomised control trial. Foot $31,23-30$.

43. Buckley R, Leighton R, Sanders D, Poon J, Coles CP, Stephen $\mathrm{D}$ et al. (2014) Open reduction and internal fixation compared with ORIF and primary subtalar arthrodesis for the treatment of sanders type IV calcaneal fractures: a randomized, multicenter trial. J Orthop Trauma 28(10), 577-583.

44. Dhillon MS, Gahlot N, Sharma S (2014) Letters to Editor. J Orthop Trauma 2(8), e302-e303.

45. Gotha HE, Zide JR (2017) Current controversies in management of calcaneus fractures. Orthop Clin N Am 28, 91-103.

46. Berberian W, Sood A, Karanfilian B, Najarian R, Lin S, Liporace F (2013) Displacement of the sustentacular fragment in intra-articular calcaneal fractures. J Bone Joint Surg Am 95, 995-1000.

47. Gitajn IL, Abousayed M, Toussaint RJ, Ting B, Jin J, Kwon JY (2014) Anatomic alignment and integrity of the sustentaculum tali in intra-articular calcaneal fractures: is the sustentaculum tali truly constant? J Bone Joint Surg Am 96, 1000-1005.

Cite this article as: Dhillon MS \& Prabhakar S (2017) Treatment of displaced intra-articular calcaneus fractures: a current concepts review. SICOT J, 3, 59 